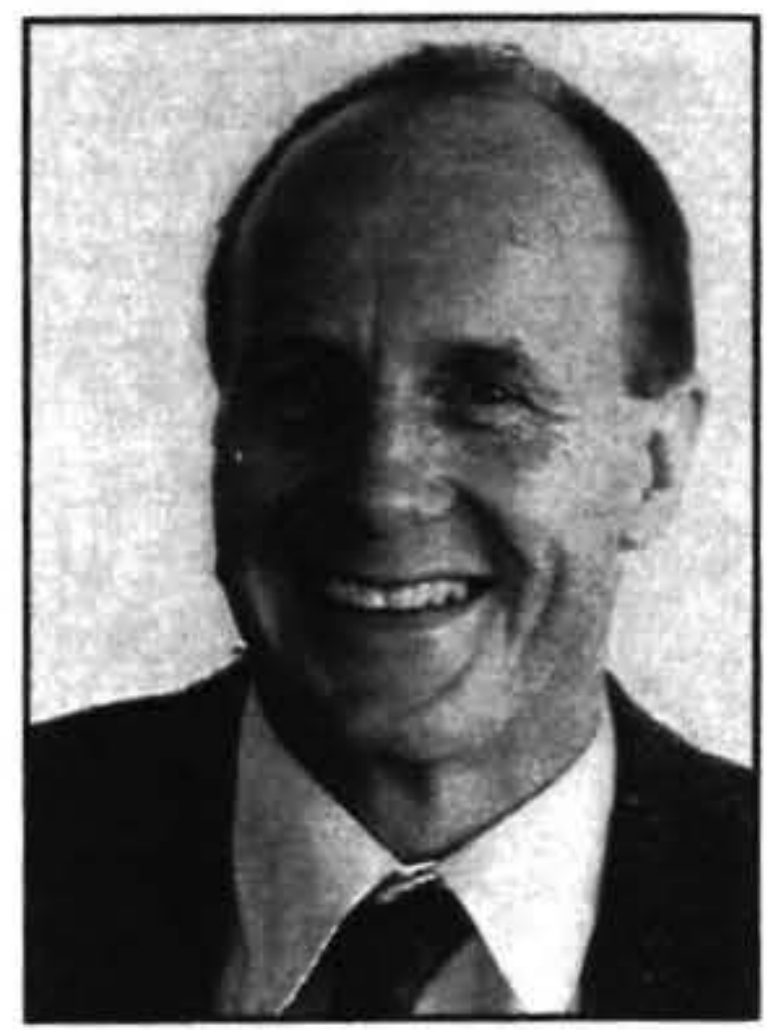

\title{
A REGIONAL LABOUR MARKET PROFILE
}

\author{
Philip S. Morrison \\ Victoria University of Wellington
}

\begin{abstract}
As unacceptably high unemployment levels persist throughout the $O E C D$ so greater attention is being paid to differences in the way regional labour markets adjust to growth and recession. Comparatively speaking New Zealand has lacked both the conceptual and empirical analyses necessary to build local and regional specific approaches into its active labour market policies - despite the persistence of regional disparities through the post war period.

When regional differences are raised for public discussion in New Zealand it is the geographical variations in the unemployment rate that usually receives attention. What this paper shows is that unemployment is merely the surface phenomenon of a condition which is much more deeply embedded in the regional labour markets affected. This is illustrated by constructing a regional labour market profile which measures each of the 14 regions on four separate labour market indicators. When applied at the height of the New Zealand recession in 1991 the profile demonstrated how regions with high unemployment rates not only experience low labour force participation rates but that when members of the labour force in such regions do find work they work fewer hours and even when fulltime employment is obtained the levels of remuneration are lower than those in the more buoyant regions. The result of these interconnected characteristics of regional labour markets is a series of indirect multipliers which serve to exagerate and compound the effect of depressed labour demand on weaker markets.
\end{abstract}

Unlike the United Kingdom where concern over regional disparities in the unemployment rate has been the driving force behind the development of regional policy, in New Zealand the regional component has only recently been considered as an integral feature of labour market policy. Considering the long running and persistent differences in unemployment across New Zealand regions throughout the post war period it is remarkable that research into the way labour market conditions vary across the local regional economies has received so little attention. ${ }^{1}$

As long as labour market programmes assumed their client groups were perfectly or even reasonably mobile there was little apparent need for a knowledge of the places and local contexts within which employment was being sought. Two decades of unstable growth and persistent recessions have changed that. Geographic mobility is now more risky and expensive but an increasing number of those with limited job prospects have begun to seek residence in low cost locations - in New Zealand (see Waldegrave and Stuart, 1997), Australia (see Wulff and Bell, 1997) as well as Europe (Markman, 1989) and the USA (Fitchen, 1995). During the 1980s recession a number of local labour markets throughout the country were not only failing to clear but were also attracting increasing numbers of the disadvantaged and less competitive members of the working age population. Increasingly unemployment is a problem that occurs in, and has to be faced by individual regions (see Bevin in this volume, and also de Bruin).
Local communities affected by rising unemployment have tried to make their voice heard by arguing for greater resources and a stronger in program formulation and while it has been the government's own intention to devolve responsibility for implementation of their programmes the revenue needs of individual localities were rarely matched by state assistance. The result has been a call to undertake the research necessary to better understand the often perplexing regional contexts within which many labour adjustment processes are now deeply embedded (see Prime Ministerial Task Force on Employment, 1994a \& b).

The devolution of some decision making to the community groups and institutions who are closest physically to the program's clients has highlighted the weakness of the local knowledge base both for local and national planning. Local data has been found thin, notwithstanding the considerable experience of many locals themselves. In many cases the numerical data that has been assembled is too highly aggregated to adequately reflect the individual community or serve the national organisations who develop, oversee and channel employment related funding to localities. And of course without the relevant information there has been little incentive to develop the conceptual and theoretical understanding necessary for their interpretation. ${ }^{2}$ As a result the regional and local labour market has been poorly served by both the academic and consulting community.

Regional labour markets are defined by the fact that local conditions are shared so that the likelihood of participating 
in the labour force, of being actually securing a job, of working a full day and of being paid a given wage or salary are closely interrelated and the nature of this correlation depends on the particular characteristics of the regional labour market concerned.

\section{The regions}

The population fifteen years and over is very unevenly spread across the fourteen regions of New Zealand: the Auckland region alone contained 28.2 percent, Canterbury 13.3 percent and Wellington 12 percent. This geographic concentration means that just under half ( 43 percent) of the country's working age groups seek work in only about a quarter (21 percent) of the country's regions.

The heavily concentrated nature of the population stands in start contrast to the map in Figure 1 which suggests a division of the country into fairly even sized regions. The fact that the smallest eight regions collectively have fewer people of working age than the single and geographically smallest region of Auckland needs to be continually born in mind in discussing regional and employment issues in New Zealand.

The best way to define a region geographically is contentious. Regional definitions are by no means obvious and are often arbitrary. The standard regions shown in Figure 1 for example are delimited on the basis of their water catchments rather than their labour catchments and as such can sometimes embrace a number of quite different local labour market areas. Ideally, in a study such as this we would begin by delimiting the labour catchments or labour sheds of the major work locations and use such groupings as local labour markets. However New Zealand has yet to invest in the identification of such functional areas even through they are widely used in Australia (DEET, 1993), the UK (see Green and Owen, 1990), as well as the USA and several European countries.

On the other hand these fourteen regions are commonly used for regional analysis in this country (see Statistics New Zealand, 1993 and Lowe, 1998) and our use of them here does at least facilitate comparisons with other statistics. Nevertheless the use of these regions should be viewed only as a first step in an analysis of sub national labour market behaviour and conclusions drawn at this level do need to be tested on more carefully delimited areas at a later date.

\section{Labour market indicators}

At any point in time, we can identify those men and women over 15 years of age (the working age population) who declare in the census that they are either not in the paid labour force $(\mathrm{N})$, in the paid labour force, holding jobs (E) or 'unemployed and actively searching for paid work' (U).

Figure 2 shows that of the 2.58 million of working age (15 years of age and over) in March 1991, one million (39.55\%) were not actually in the labour force, that is, they were not in paid work or unemployed and looking for work. Of the 1.561 million who were in the labour force nearly $1.4(90 \%)$
Figure 1. Regions of New Zealand

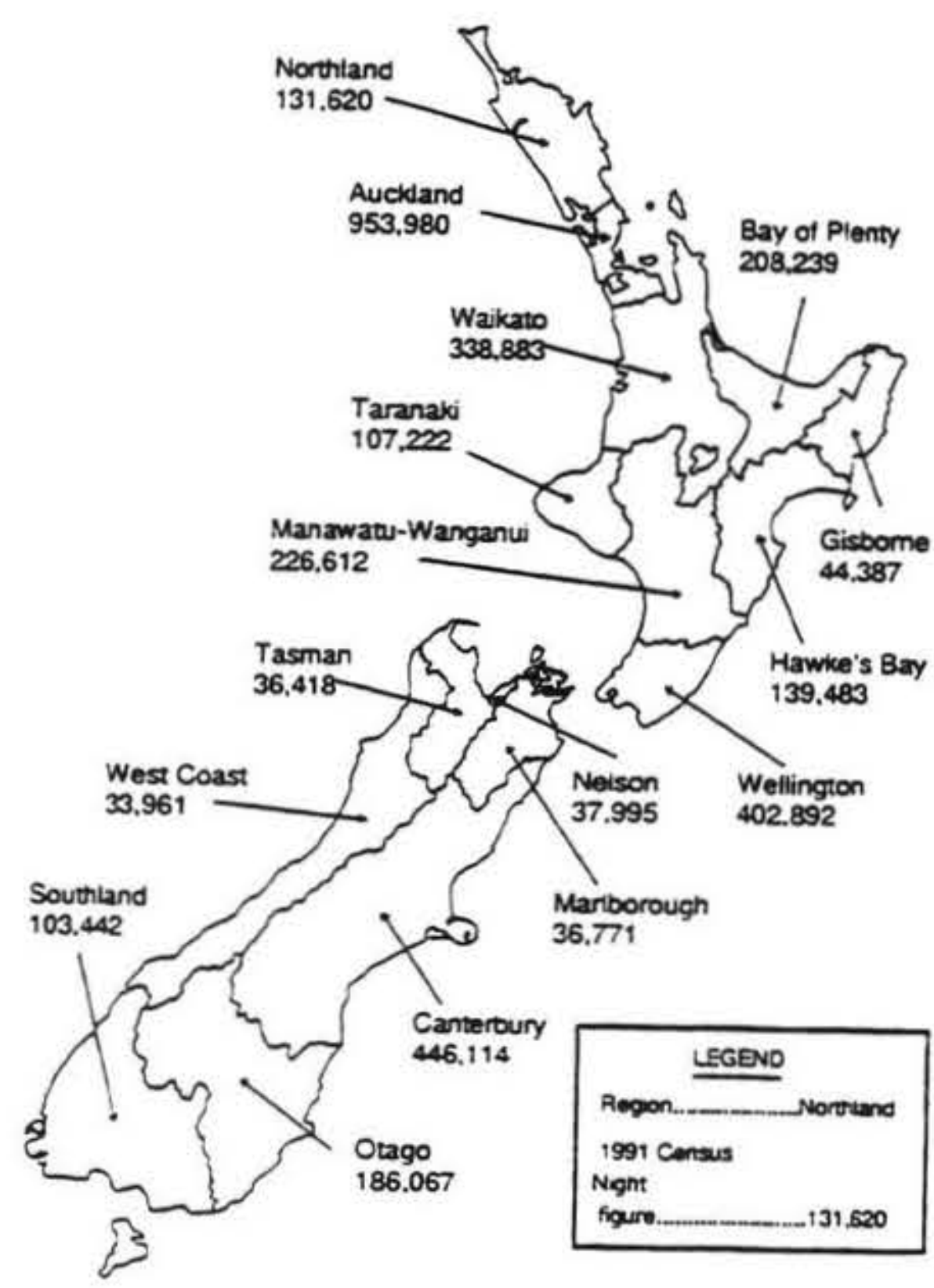

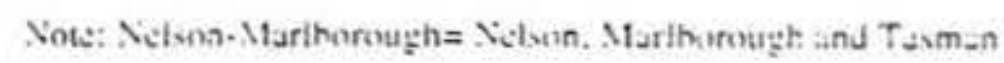

Source: Statistics New Zealand 1997 Introduction to the census SNZ page 40

were employed (either part-time or fulltime) and $0.16 \mathrm{mil}$ lion $(19 \%)$ were unemployed.

The first of two indicators may be constructed by expressing these three core measures, $\mathrm{E}, \mathrm{U}$ and $\mathrm{N}$ as ratios of one another. The labour force participation rate (LFPR) = $(\mathrm{E}+\mathrm{U}) /(\mathrm{E}+\mathrm{U}+\mathrm{N})=\mathrm{LF} / \mathrm{WAP}+$. The second indicator, the unemployment rate, is the number of unemployed and seeking work (U) divided by the labour force (LF) that is, $\mathrm{UNR}=\mathrm{U} / \mathrm{E}+\mathrm{U})=\mathrm{U} / \mathrm{LF}$ ). These terms are elaborated in Appendix 1.

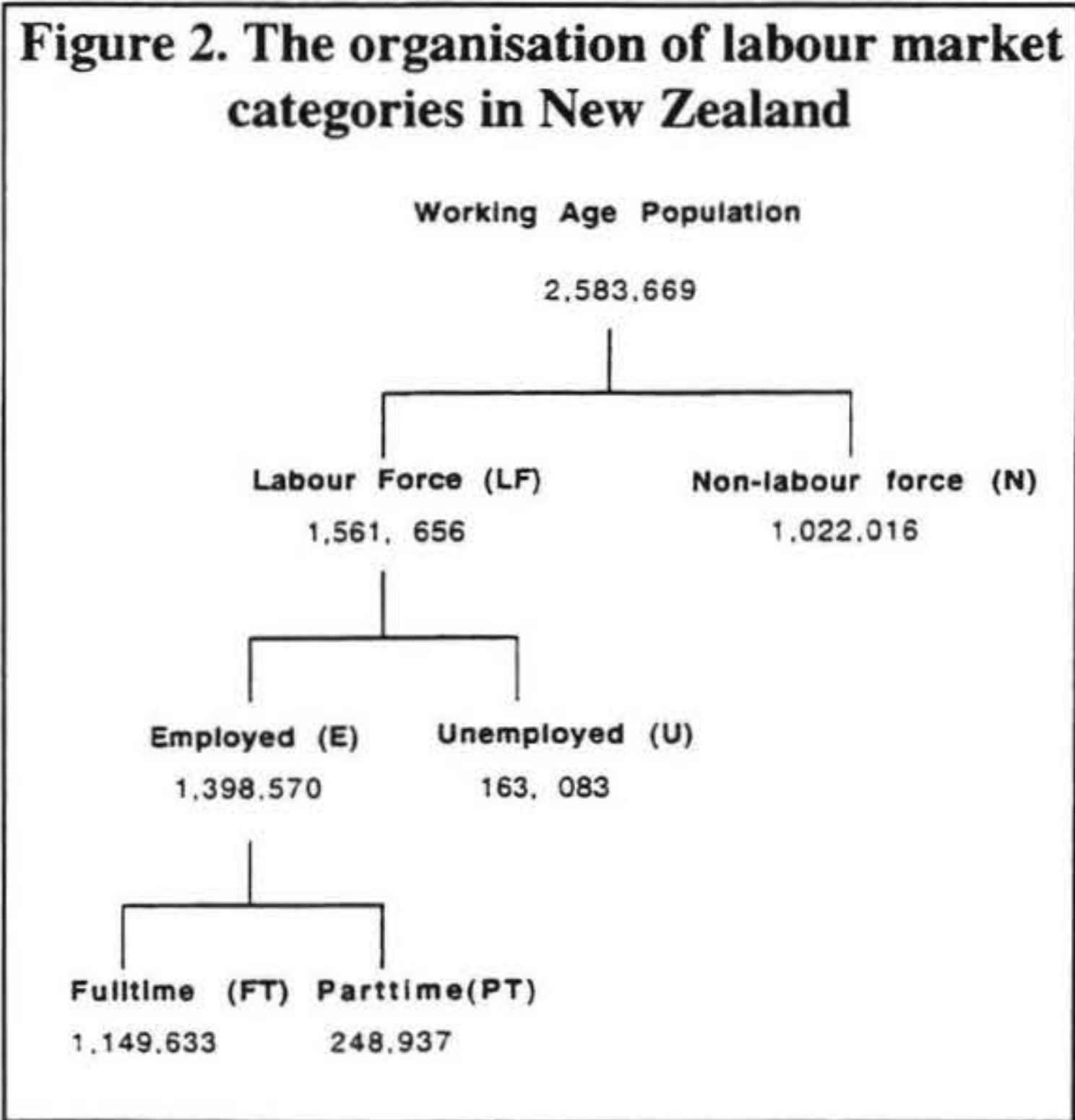

Labour, Employment and Work in New Zealand 1996 
According to the census, being employed involves working for an hour or more a week and therefore a wide range of possible employment periods are possible. The conventional division of the employed by hours of work is between those who work less than thirty hours a week (part-timers) and those who work thirty or more hours per week (full timers). This mix is captured in our third indicator, the fulltime work rate, FTWR $=\mathrm{FT} /(\mathrm{FT}+\mathrm{PT})=\mathrm{FT} / \mathrm{E}^{3}$

The fourth indicator we use to monitor labour markets is the total annual income reported by fulltime wage or salary earners. ${ }^{4}$ Although still a 'total income' rather than a solely 'wage income' measure, well over ninety percent of all income earned by wage and salary earners actually comes from this source. In addition to being a convenient proxy for wage or salary income when applied to fulltime wage and salary earners this measure has the additional advantage of avoiding the income effect of variations in the mix of full and part-time work across the regions (as well as the implicit correlation with our previous indicator, the fulltime work rate).$^{5}$

\section{Regional differences in labour market condition}

The four labour market indicators together with the census counts used to construct them are given in Table 1. The labour force participation rate ranges from a low of 55.8 percent in Northland to a high of 63.9 percent in Wellington. The plots in Figure 3 shows that Wellington, Southland, Auckland and Waikato are noticeably higher than the other regions with participation rates of over 61 percent. The next cluster is Taranaki and Nelson-Marlborough at around 60 percent with a third cluster of Hawke's Bay, Canterbury, Manawatu-Wanganui and West Coast between 58 and 59 percent. These are followed by Bay of Plenty and Otago with between 57 and 58 percent. Even though Gisborne and
Northland trail the field, the participation rates in these regions are not markedly lower than the New Zealand average of 60.4 percent suggesting a slightly narrower range than found internationally. ${ }^{6}$

Although not immediately obvious from Figure 3, unemployment rates do show a much wider distribution across the regions than the labour force participation rate. The standard deviation of the rates relative to their mean (the coefficient of variation) is 15.9 for unemployment compared to only 4.1 for the labour force participation rate.

Also, unlike the more evenly distributed labour force participation rate, there is a distinct regional clustering to the unemployment rate with Northland at 14.3 percent, Gisborne at 13.3 percent followed by the Bay of Plenty with 13.2 percent. Several points below, at $10-11$ percent, is a cluster of six regions, Hawke's Bay, Manawatu-Wanganui, Waikato, Taranaki, Otago and Auckland. Almost a percentage point lower is Canterbury with Wellington, Southland and Nelson-Marlborough experiencing the country's lowest unemployment rates. The New Zealand range from 8.6 percent to 14.3 percent at the height of the country's recession in 1991 would appear to be well within the range encountered in other OECD countries.?

Our third labour market indicator is the proportion of the employed holding jobs of more than thirty hours a week. Like the labour force participation rate the Wellington and Auckland labour markets stand apart from the rest of the country (with 83.9 and 83.6 percent holding fulltime jobs respectively). By contrast the less urbanised regions of Waikato, Southland, West Coast and Taranaki and then Gisborne have relatively fewer of their employed working fulltime. Below the median in a bunch are ManawatuWanganui, Otago followed by Canterbury, Bay of Plenty, Hawke's Bay, Nelson-Marlborough and Northland, all

Table 1. Selected labour market measures by Regional Council, New Zealand, 1991

\begin{tabular}{|c|c|c|c|c|c|c|c|c|c|c|c|}
\hline Region & Unemployed & $\begin{array}{l}\text { Fullime } \\
\text { employed }\end{array}$ & $\begin{array}{l}\text { Part-lime } \\
\text { employed }\end{array}$ & Employed & Labourforce & $\begin{array}{l}\text { Non-labour } \\
\text { torce }\end{array}$ & $\begin{array}{l}\text { Working age } \\
\text { population }\end{array}$ & $\begin{array}{c}\text { Labour force } \\
\text { participation } \\
\text { rate }\end{array}$ & $\begin{array}{c}\text { Unemployment } \\
\text { rate }\end{array}$ & $\begin{array}{l}\text { Fullime } \\
\text { work rate }\end{array}$ & $\begin{array}{l}\text { Per capita } \\
\text { income }\end{array}$ \\
\hline & $u$ & FT & PT & $E$ & u & $\mathbf{N}$ & WAP & LFPA & UNA & FTWA & $\mathbf{s}$ \\
\hline Northland & 7.437 & 35.751 & 8.685 & 44.436 & 51.876 & 41,112 & 92.988 & 55.8 & 14.3 & 80.5 & 19.656 \\
\hline Auckland & 46.995 & 337.779 & 66,444 & 404,223 & 451.215 & 276.834 & 728.049 & 620 & 10.4 & 83.6 & 22.320 \\
\hline Waikato & 16,107 & 111.153 & 23.757 & 134.910 & 151.017 & 95,370 & 246.387 & 613 & 10.7 & 824 & 20.796 \\
\hline Bay of Plenty & 11.580 & 61.488 & 14.745 & 76.233 & 87.816 & 64.014 & 151.830 & 578 & 132 & 807 & 20.331 \\
\hline Gisbome & 2.400 & 12.726 & 2.931 & 15,657 & 18.060 & 14.088 & 32.148 & 562 & 133 & 813 & 17,157 \\
\hline Hawke's Bay & 6.720 & 43.809 & 10,554 & 54,363 & 61.083 & 42.531 & 103.614 & 590 & 11.0 & 80.6 & 18.912 \\
\hline Taranaki & 5.100 & 34.962 & 7.836 & 42.798 & 47.898 & 31.902 & 79.800 & 60.0 & 10.6 & 81.7 & 20.616 \\
\hline Manawatu-Wanganui & 10.890 & 71.976 & 16.881 & 88.857 & 99.747 & 70.218 & 169.965 & 587 & 10.9 & 81.0 & 20.163 \\
\hline Wellington & 17.772 & 151.377 & 29.049 & 180.426 & 198.198 & 111.930 & 310,128 & 639 & 9.0 & 83.9 & 23.231 \\
\hline Nelson-Marlborough & 4.320 & 36.915 & 8.883 & 45.798 & So. 118 & 33.534 & 83.652 & 599 & 8.6 & 80.6 & 18.786 \\
\hline West Coast & 1.554 & 10.677 & 2,346 & 13.023 & 14.574 & 10,353 & 24.927 & 58.5 & 10.7 & 820 & 20.289 \\
\hline Canterbury & 19,704 & 147.447 & 35.322 & 182.769 & 202.470 & 141.771 & 344.241 & 588 & 9.7 & 80.7 & 20.007 \\
\hline Otago & 8,400 & 58.149 & 13.728 & 71.877 & 80.277 & 60.414 & 140.691 & 571 & 10.5 & 80.9 & 19.424 \\
\hline Southland & 4.086 & 35,130 & 7.686 & 42.816 & 46.902 & 27,819 & 74,721 & 62.8 & 8.7 & 820 & 19.893 \\
\hline Not Applicable & 18 & 294 & 90 & 384 & 405 & 129 & 534 & 75.8 & 4.5 & 76.6 & \\
\hline NEW ZEALAND & 163.083 & $1,149.633$ & 248,937 & 1.398 .570 & $1,561,656$ & $1,022.019$ & 2.583 .675 & 60.4 & 10.4 & 822 & \\
\hline \multicolumn{12}{|l|}{ Statistics } \\
\hline Minimum & 1.554 & 10.677 & 2.346 & 13.023 & 14.574 & 10.353 & 24.927 & 55.8 & 8.6 & 805 & 17.157 \\
\hline Maximum & 46,995 & 337.779 & 66,444 & 404.223 & 451.215 & 276.834 & 728.049 & 639 & 14.3 & 839 & 23.231 \\
\hline Range & 45.441 & 327,102 & 64.098 & 391,200 & 436.641 & 266.481 & 703.122 & 8.1 & 5.7 & 34 & 6.074 \\
\hline Median & 7.919 & 50.979 & 12.141 & 63.120 & 70.680 & 51.473 & 122.153 & 58.9 & 10.7 & B1.1 & 20.085 \\
\hline Mean & 11.648 & 82.096 & 17.775 & 99.870 & 111.518 & 72.992 & 184.510 & 594 & 10.8 & 816 & 20.113 \\
\hline Standard deviation & 11.655 & 86.106 & 16.958 & 102,993 & 114.570 & 69.708 & 184,088 & 2.4 & 1.7 & 11 & 1.470 \\
\hline Coefflicient of Var. & 100.1 & 104.9 & 95.4 & 103.1 & 102.7 & 95.5 & 99.8 & 4.1 & 15.9 & 1.4 & 7.3 \\
\hline
\end{tabular}

Source: Statistics New Zealand Census of Population and Dwellings, via SUPERMAP2 
Figure 3. The regional distribution of labour market indicators, New Zealand, 1991
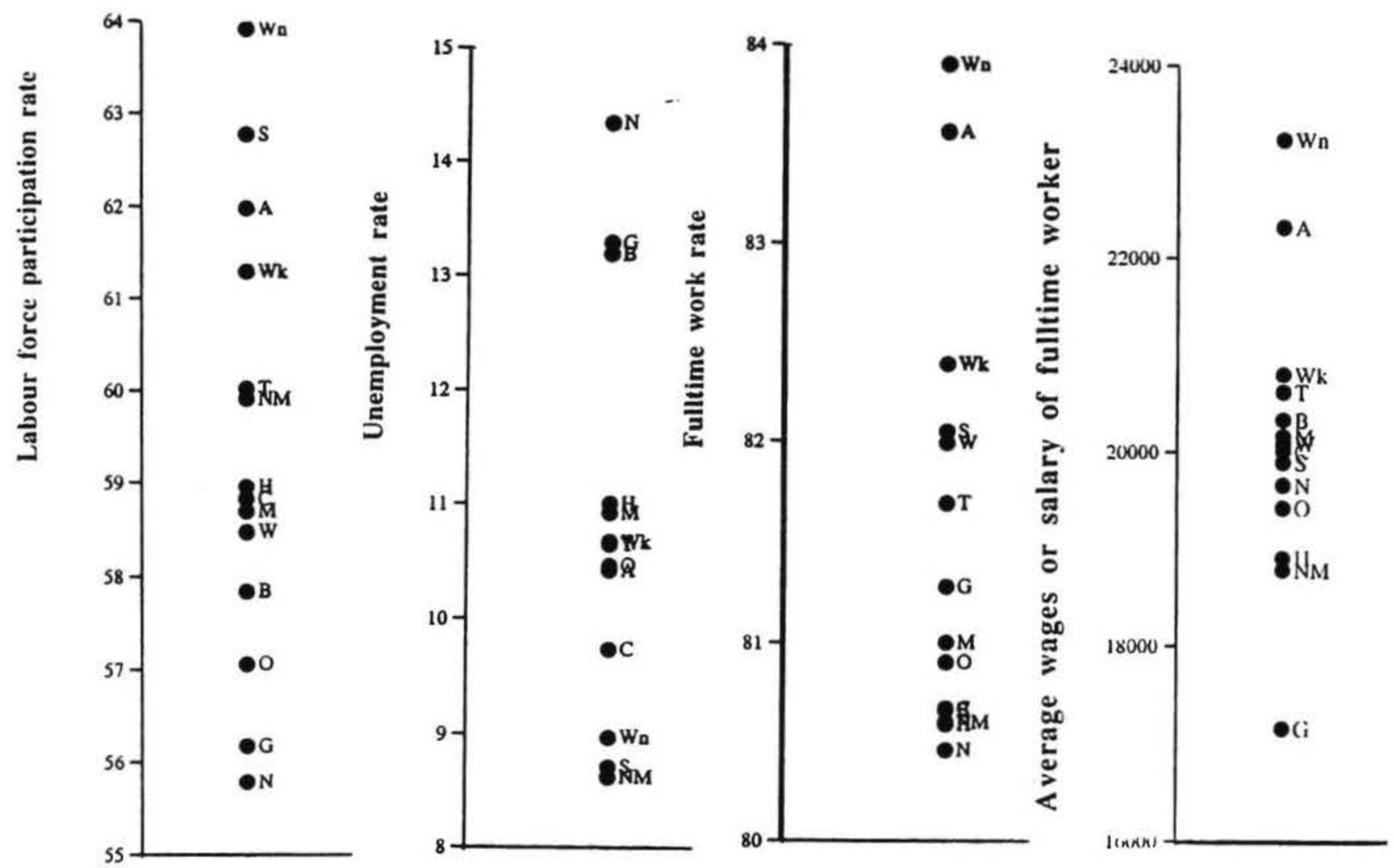
A - Auckland
H- Hawke's Bay
NM-Nelson-Marlborough
S-Southland

\author{
Wk- Waikato \\ T - Taranaki \\ W-West Coast
}
B- Bay of Plenty
M- Manawatu-Wanganui
C- Canterbury

showing the larger proportion their workforce in part-time rather than fulltime employment.

Finally in the fourth panel of Figure 3 is the variation in average total income of fulltime wage and salary earners across the regions. This panel clearly depicts the higher returns to fulltime work in Wellington and Auckland. Earning several thousand 1991 dollars less per annum than those in the metropolitan centres were the fulltime workers in Taranaki, Canterbury, Waikato and the Bay of Plenty. Successively lower wages were earned by fulltimers living in Manawatu-Wanganui, Otago, Southland, Northland, West Coast and Hastings with the lowest income reported by those fulltimers in Nelson-Marlborough and Gisborne. ${ }^{8}$

In summary, while New Zealand may not show quite the labour market diversity of many larger economies like the USA, Europe or even the UK, the regional differences that do exist are quite marked.

The joint presence of disadvantage on all four indicators is only just being identified internationally as a characteristic of depressed regional labour markets. In a recently published paper UK readers were reminded of just how contemporary regional and local unemployment differentials underestimate the true extent of geographical disparities in labour market opportunity: "a larger proportion of those who are in employment in [depressed] regions tend to be in 'marginal' employment"...and that..."the use of the conventional [unemployment rates] as an indicator of such reserves tends to understate not only the size of these reserves but also the scale of regional differentials in their distribution (Green and Hasluck, 1998: 552, 556). ${ }^{9}$

The next step is to appreciated just how the four indicators - the unemployment rate, the labour force participation rate, fulltime work rate and fulltime wages - are correlated across the regions. Each indicator describes one complementary aspect of an overall picture of the labour market in the region and its intercorrelation is of special significance for two reasons. The first is the way each indicator contributes incrementally to the overall income of the labour force in the region. Annual incomes bear a direct relationship to the number of hours worked, the number of days and of course the wage rate. The first three of our indicators are especially relevant for, as Mead has emphasised elsewhere, it is 'differences in hours worked, not in wages, principally determine whether workers are poor' (Mead, 1992:69-70). The same is true of regions in general.

The strength of the intercorrelation among the indicators becomes important in studying how regional labour markets 


\section{Figure 4 The regional labour market profile. Basic structure}

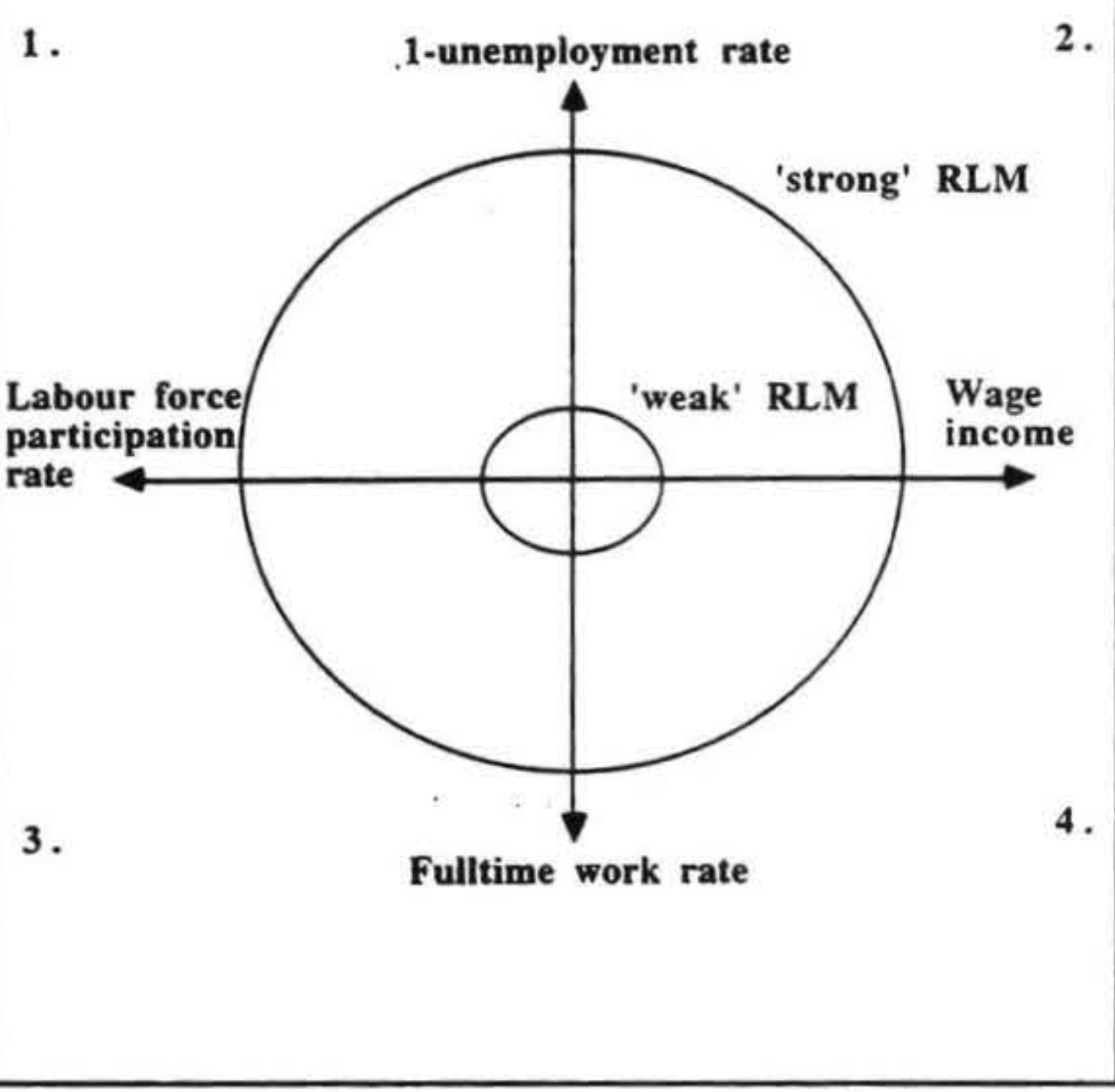

adjust to changes in the growth of the overall economy. This aspect is not explored here but it is likely that in subsequent analysis we will find that different indicators will change at different rates and magnitudes than others and that their relative importance will vary from one region to another (a feature already well documented for unemployment by Vedder and Gallaway, 1996).

\section{The regional labour market profile}

The regional labour market profile is a graphical device designed to, a) illustrate the nature of the correlation between the four indicators, b) show the relative position of each region with respect to each indicator and, c) to assist in the classification of labour market types.

Figure 4 shows how the profile is organised. Note firstly how the value of each indicator increases outwards from the central point of intersection and that the scales are orientated accordingly. In order to ensure that higher magnitudes are associated with positive labour market outcomes we subtract the unemployment rate from 100 giving the ' 1 -unemployment rate'. With this adjustment regions located further from the central origin of the profile are deemed to be subject to stronger labour demand.

By contrast, regions experiencing relatively depressed demand for labour will appear near the centre of the graph; a smaller proportion of the working age populations will be participating in the labour market and, when they do, more will be experiencing unemployment. When members of these markets are employed they will be offered less work (part-time rather than fulltime) and, those that do receive fulltime work will receive remuneration lower than those in other regions.

Figure 5 shows how regions might appear in such a plot.
Figure 5 The regional labour market profile. Strong and weak markets.

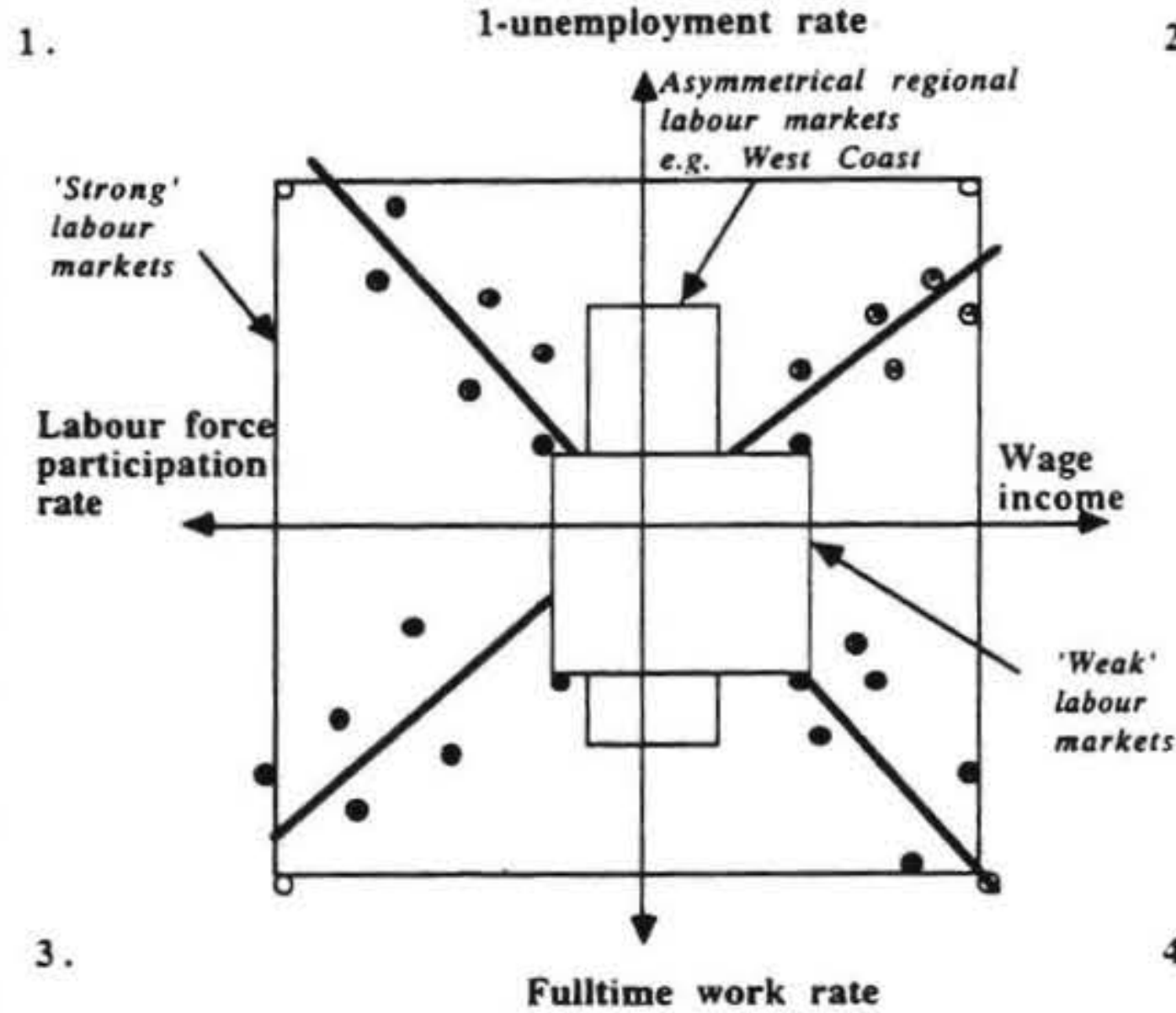

Each region appears four times, once in each panel. By connecting the same region across the four panels we create a 'box' whose shape will vary from region to region according to their relative position on each of the indicators. For example boxes labelled S and W in Figure 5 connect 'strong' and 'weak'regional markets respectively. The oblong (characteristic of the 'West Coast') illustrates an asymmetrical labour market characterised by lower labour force participation rates but low levels of unemployment. Such a shape suggests that those who are working are more likely than most other regions to be in fulltime work, but that such workers also have to support a relatively larger non-working population on relatively lower wages.

The plot of the regions within each of the panels therefore allows both the nature and strength of their intercorrelation to be observed.

\section{Applying the regional labour market profile}

The four plots which make up the profile are created from the four indicators given in Table 1. The resulting profile in Figure 6 shows how each region 'performs' on each of the four dimensions. In panels one, three and four the positive correlations are moderate to strong, with over half the statistical variation in one indicator being accounted for by its pair; r-squared values are $.57, .61$ and .59 respectively. The third correlation, relating the employment rate to fulltime wage incomes, while still positive, has a lower r-square of 0.13 . These coefficients of determination correspond to the conventional Pearson correlations of $r=0.76,0.78,0.77$ and 0.36 respectively. We will now explore the results in each of these panels in turn.

Panel 1 of Figure 6 confirms the positive relationship between labour force participation and the (un)employment 
Figure 6. A regional labour market profile applied to New Zealand, 1991

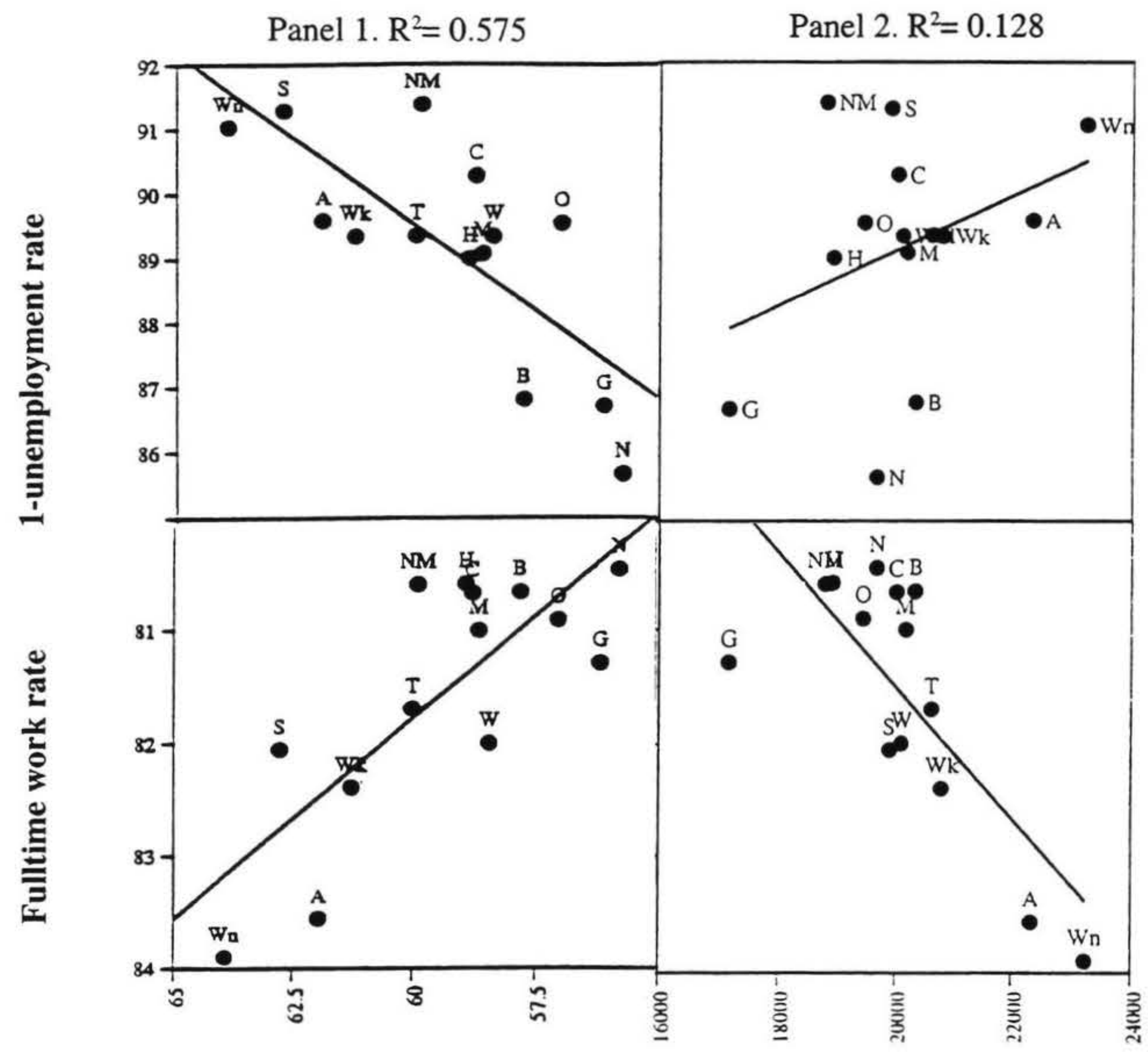

Panel 3. $R^{2}=0.610$

Panel 4. $\mathrm{R}^{2}=0.589$

Labour force participation rate

Wage or salary income
N - Northland
G- Gisborne
Wn-Wellington
O-Otago
A - Auckland
H- Hawke's Bay
Wk- Waikato
T - Taranaki
NM-Nelson-Marlborough W-West Coast
S-Southland
B- Bay of Plenty
M- Manawatu-Wanganui
C- Canterbury

rate which is widely discussed in the literature (see especially Bowen and Finegan, 1969). Regions with relatively high overall unemployment experienced low participation rates while those regions with relatively low unemployment rates such as Wellington, Southland, Nelson and Marlborough and Auckland experience relative high rates of participation.

While such a positive correlation has been used in the literature to confirm the dominance of discouraged worker effects over added worker effects within regional economies this single interpretation may overstate the behavioural aspects and understate the compositional and structural features which go into producing such an empirical pattern (see Fleischer and Rhodes, 1976). It is just as likely that, rather than being solely a result of a causal behavioural association both variables could be reflecting responses to differences in the regional demand for labour (as well as the supply characteristics that follow as a result - through migration for example).

High local demand for labour generates higher levels of labour force participation as more people are willing to search for work. Job search costs are reduced and this increases the expected returns to participation by upward pressure on wages and salaries. Higher demand for labour leads to more fulltime work and lower rates of unemployment. In a small economy such as New Zealand economies of scale ensure that these pressures on the labour market are heavily concentrated in one or two major centres thus moving these metropolitan markets away from the other regional markets on almost all indicators. 


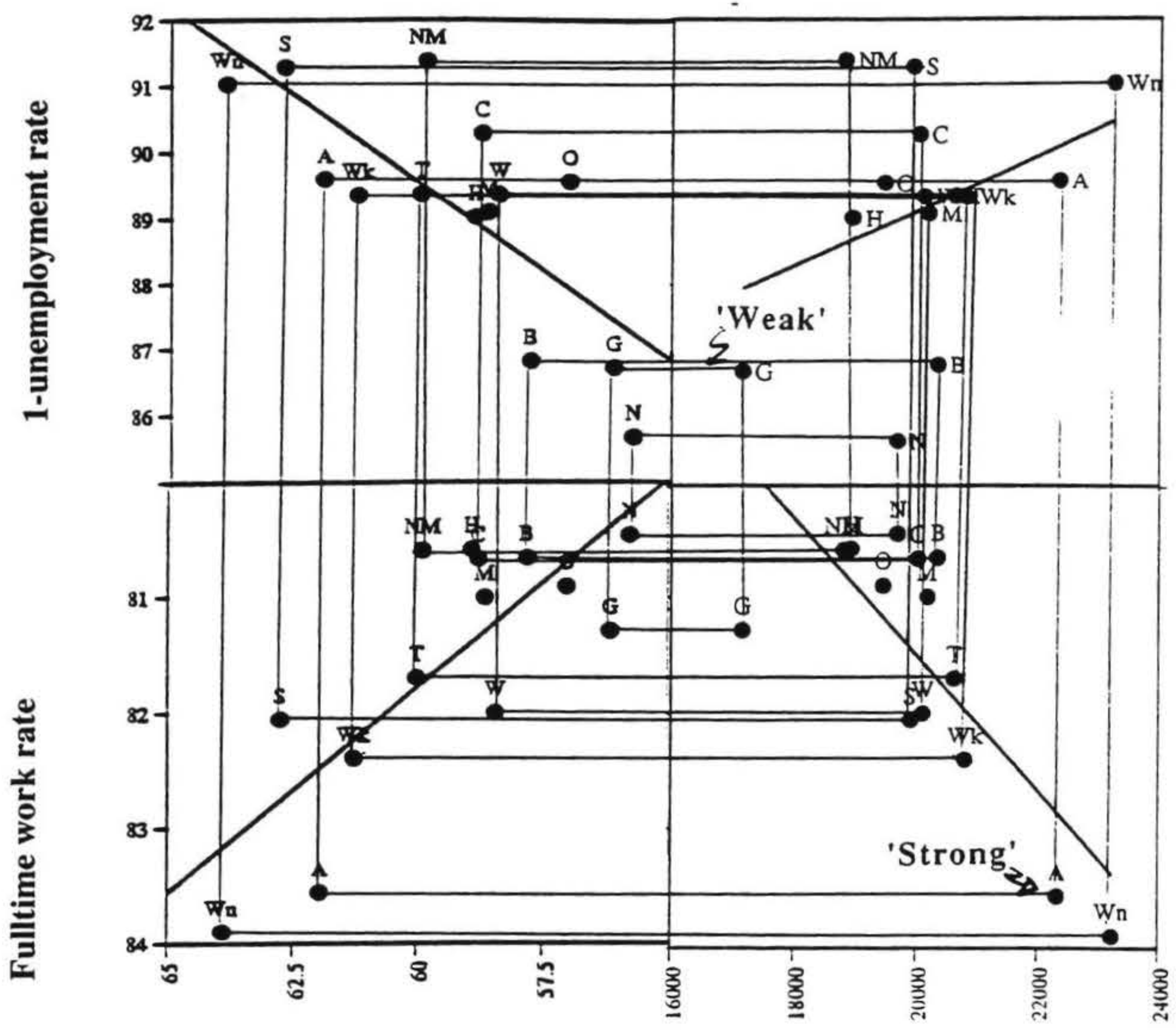

Labour force participation rate

Wage or salary income

$\begin{array}{lll}\text { N-Northland } & \text { A-Auckland } & \text { Wk- Waikato } \\ \text { G- Gisborne } & \text { H- Hawke's Bay } & \text { T- Taranaki } \\ \text { Wn-Wellington } & \text { NM-Nelson-Marlborough } & \text { W-West Coast } \\ \text { O-Otago } & \text { S-Southland } & \end{array}$
B- Bay of Plenty
M- Manawatu-Wanganui
C- Canterbury

O-Otago S-Southland

Turning to panel 2 of Figure 6 the expectation here is that regions exhibiting low unemployment rates (high 1-unemployment rates) will also experience higher pressures on wages. ${ }^{10}$ In this case the statistical correlation is less strong. One of the reasons is the presence of two outliers: NelsonMarlborough and Southland. These are both heavily seasonal economies which show much higher rates of employment within the labour force than expected on the basis of their relatively low wages incomes. Without these regions the correlation between the regional unemployment rate and regional fulltime incomes would increase to $R^{2}=0.34 .^{11}$

Labour can be expected to be attracted into paid work by the greater earning opportunities which fulltime work offers - a feature confirmed by the relatively strong result in panel 3 of Figure 6. Regions like Northland and Gisborne but also
Hastings, Canterbury and Manawatu-Wanganui as well as Otago not only have low labour force participation rates but have low fulltime work rates as well. Wellington and Auckland on the other hand have both high participation and fulltime work rates.

Finally, panel 4 of Figure 6 confirms the expected positive relationship between hours of work and the nominal average wage or salary income of fulltime workers in the regions. This suggests that the more likely fulltimers are to be hired, the more likely they are to be better paid. Noticeable here again is the strong influence exerted by Auckland and Wellington, although the regional economies of Waikato, Taranaki, Southland and the West Coast clearly separate themselves from those regions in which part-time work is more common. 
In summary, we have been able to demonstrate that labour demand is manifest in consistent ways throughout the different regional markets: strong markets offer more paid work, longer hours and higher wages. Weaker regional markets are able to offer less work thus raising the chances of unemployment, and when they employment they supply fewer hours per week and even when fulltime work is available it is at lower wages than in the more buoyant regional economies. ${ }^{12}$ Weaker regions therefore experience multiple and compounding labour market disadvantages.

\section{Regional labour market types}

At least four different types of regional labour markets can be identified from such a regional profile - see Figure 7. The first is the relatively straightforward contrast between the two North Island metropolitan labour markets Auckland and Wellington and the rest of the regions - particularly noticeable in the case of the labour force participation rate and the fulltime wage and although unemployment rates are not necessarily lower it is highly likely that unemployment spells are lower and turnover higher in such regions. The second are the weaker economies of Northland, Gisborne and Bay of Plenty located near the centre of the plot. ${ }^{13}$

Thirdly, it is possible to discern two asymmetrical market types which lie midway between the first two: type $\mathrm{A}$ in which low labour force participation rates combine with higher rates of part-time work and with lower-middle wage incomes in regions with low unemployment: NelsonMarlborough, Canterbury, Hastings, Manawatu-Wanganui and Otago.

Type B regional labour markets - West Coast, Taranaki, Waikato and Southland - show higher than average proportions of people in the labour force and higher than average fulltime work rates in regions where unemployment and fulltime salaries are about average. In these economies, while fulltime work rates are much lower than type A, unemployment is higher but wage incomes appear to be relatively similar.

In summary, the profile allows us to identify regions whose labour markets exhibit similar characteristics. The next step is to find out why regions take on these characteristics and how these affect the way these different economies adjusted to economic growth over the period 1991-1996. Of particular interest will be the degree to which a region's relative position on each of these indicators changed as the economy picked up between 1991 and $1996 .^{14}$

\section{Conclusion}

When regional differences are raised in public discussion in New Zealand it is the disparity in unemployment rates that has usually received attention. What this paper has demonstrated is that unemployment is merely the most well known of a set of labour market conditions which together penetrate much more deeply into the areas affected than unemployment alone.
By relating four separate labour market indicators within a single regional labour market profile we have been able to show not only that regions with high unemployment have fewer residents who declare themselves part of the labour force, but that when they do secure work, a larger proportion is part-time work, and even when fulltime work is secured the level of remuneration is lower than in other more buoyant regions.

What these results highlight therefore is the wide ramifications of differential labour demand across the regions. The combined effect of these indicators considerably widens regional disparities in labour market opportunity,lowering aggregate regional (personal) incomes and to bring more individuals in the weaker markets closer to the poverty line. Were we able to include measures on the duration of work we would undoubtedly find that regions with high unemployment and less fulltime work would also only be able to offer shorter spells of work - further lowering annual incomes of disadvantaged regions. An advantage of the profile therefore is that it allows us to focus on the multiple ways in which a local labour market can affect returns to waged work across the country and how these compound the difficulties faced by those living in adversely affected regions.

We began this paper with the observation that as unacceptably high unemployment levels persist throughout the OECD so greater attention is being paid to regional differences labour adjustment dynamics. We argued that, comparatively speaking, New Zealand has lacked both the conceptual and empirical analysis necessary to build local and regional specific approaches into its active labour market policies. While not exactly a panacea, this exploration has emphasised the importance of viewing the location labour market as a set of interrelated conditions which highlight the way in which the conditions which generate unemployment and affect several other labour market measures as well compound and amplifying the impact of living in bouyant and adversely affected regions in turn.

\section{Future research}

The regional profile is a largely descriptive device. However the theoretical bases of expected relationships within each of the four panels means that the profile can be employed to test specific hypotheses about what can be expected to happen to the different regional labour markets during periods of national growth and recession.

By being based on readily accessible census data such profiles can easily be assembled for different types of labour force participants; so for example we can look at how the behaviour of young men in different regions alters during recessions compared to say older, more established members of the labour force. Are the young more readily absorbed into the labour market with economic growth in some regions than others for example? What levels of work do they get and how do their return to waged work differ across the country? Do these results apply equally to both men and women and to those with limited and extensive 
formal education? And so on.

Finally, one of the perennial issues surrounding sub national analysis of labour markets is the impact of drawing boundaries between regions. New Zealand has yet to invest in the identification of local labour markets per se as opposed to simply using those based on water catchments as is the case here. Until we take such steps the usefulness of any conceptual framework will remain hostage to our official rather than actual labour geography.

\section{APPENDIX 1: Glossary of terms and expressions.}

The following is designed to amplify the terms used in the construction of Table 1 .

1. The labour force participation rate (LFPR $=\mathrm{LF} / \mathrm{WAP})$

2. The unemployment rate (UNR-UN/LF)

3. The full-time work rate (FTWR=FT/WF) where $\mathrm{WF}=$ workforce $=\mathrm{PT}+\mathrm{FT}$.

The labour force is defined by the census as consisting of persons aged 15 years and over who regularly work for one or more hours per week for financial gain, or as an unpaid worker in a family business. Also included are persons who are unemployed and actively seeking either fulltime or parttime work. Unpaid voluntary work is not included. Therefore the labour force, $\mathrm{LF}=\mathrm{FT}+\mathrm{PT}+\mathrm{UN}$. Note FT and PT as defined here does not include the unemployed. However if referred to as the 'full-time labour force' (or 'part-time labour force'), then those unemployed and actively searching for full time (part-time) is included.

The work force (as opposed to the labour force) is not an official census term but is defined here as the labour force excluding the unemployed (UN), so WF+LF-UN=FT+PT.

The full-time work rate (FTWR) is the number of working full-time (working 30 hours a week or more) divided by the total workforce i.e. FTWR-FT/(FT+PT)=FT/WF.

Unemployed and seeking work refers to persons who were not working in a paid job, business, farm or profession at census data, but had looked for either fulltime or part-time work in the preceding four weeks. The 1986 definition included 'regardless of their availability and the job search methods used'. (Looking at job advertisements in newspapers alone was not considered actively looking for work). In 1991 to be included as unemployed and seeking work you would have had to be willing to start work in the week preceding the census if a job had been available.

The part-time labour force comprises those aged 15 years and over working 1 to 29 hours per week, and those persons aged 15 years and over who are unemployed and actively seeking part-time work.

\section{Acknowledgments}

This paper is based on work undertaken for the Labour Market Policy Group, Department of Labour. I wish to thank David Maré and staff for their comments on an earlier draft. The views expressed in this paper are those solely of the author and are not to be attributed to the Department of Labour.

\section{References}

Bevin, S. 1997 Local authority responses to unemployment. In P.S. Morrison (ed.) Labour, employment and work in New Zealand. Proceedings from the Seventh Conference, Institute of Geography, Victoria University of Wellington:

Bowen, W.G. and T.A. Finegan 1969 The economics of labour force participation Princeton University Press: Princeton

Bowers, J. 1970 The anatomy of regional activity rates Regional Papers 1, NIESR, Cambridge University Press

Brooks, R. 1991 Male and female labour force participation in New Zealand 1965-1990: a cointegration analysis New Zealand Economic Papers 25: 219-251

de Bruin, A. 1997 Community employment creation in an urban labour market. In P.S. Morrison (ed.) Labour, employment and work in New Zealand. Proceedings from the Seventh Conference, Institute of Geography, Victoria University of Wellington: $88-95$

DEET, 1993 Small area labour markets. Australia Economic and Policy Analysis Division, Department of Employment, Education and Training

Fitchen, J.M. 1995 Spatial redistribution of poverty through migration of poor people to depressed rural communities Rural Sociology 60(2): 181201

Fleischer, B.M. and G. Rhodes 1976 Unemployment andthe labour force participation of married men and women: a simultaneous model Review of Economics and Statistics 58: 398-406

Gordon, I.E. 1970 Activity rates: regional and sub-regional differentials Regional Studies 4, 411-424

Green, A.E. and D.W. Owen 1989 Labour market accounts for travel-to-work areas Regional Studies 23: $69-72$

Green, A.E. and C. Hasluck 1998 (Non) participation in the labour market: alternative indicators and estimates of labour reserve in United Kingdom regions Environment and Planning $A$ 30: 543-558 
Hall, R.E. 1972 Turnover in the labour force Brookings Papers on Economic Activity 3:709-764

Harkman, A. 1989 Migration behaviour among the unemployed and the role of unemployment benefits Papers of the Regional Science Association 66: $143-150$

Harris, R. and L. Raney 1991 Participation and the supply of hours for New Zealand females in 1986: differences across ethnic groups. Proceedings of the New Zealand Association of Economist conference, Auckland.

Hyclak, T. and G. Johnes 1987 On the determinants of full employment unemployment rates in local labour markets Applied Economics 19: 191. 200

Hyman, P. 1978 Trends in female labour force participation in New Zealand since 1945 New Zealand Economic Papers 12: 156-167

Hyman, P. 1979 Inter-urban variation in female labour force participation in New Zealand, 1971 New Zealand Economic Papers 13, 115-139

Jackson, L. F. 1997 Changes in regional incomes 1986 to 1991. In P.S. Morrison (ed.) Labour, employment and work in New Zealand. Proceedings from the Seventh Conference, Institute of Geography, Victoria University of Wellington: 67-76

Jensen, R.C. 1969 Regional income inequalities and employment shifts in New Zealand New Zealand Economic Papers 3(2): 27-50

Johnston, R.J. 1981 Inter-regional and inter-urban income variations in New Zealand Pacific Viewpoint September: 147-159

Lowe, R.J. 1988 Abstract of New Zealand Regional Statistics Town \& Country Planning Directorate, Policy Division, Ministry of Works

Mabbett, D. 1988 Regional policy. In the April Report: report of the Royal Commission on Social Policy. Vol 3, Part 1. In Appendix to the Journal of the House of Representatives of New Zealand, H, 2: 659-690.

Mead, L. M. 1992 The new politics of poverty. The non working poor in America New York: Basic Books

Molho, I.I. 1983 A regional analysis of the distribution of married women's labour force participation rates in the UK Regional Studies 17(2): 125-134

Morrison. P.S. 1998a Regional variation in labour market indicators. A report prepared for the Labour Market Policy Group, Department of Labour.
Morrison, P.S. 1998b Unemployment and labour force participation in the 1990s. The New Zealand experience. Chapter in K. O'Conner and D. Mercer (eds) Housing, people and Cities: essays in honour of Chris Maher. Monash University (forthcoming)

Munro, J. M. and G. Schacter 1998 Regional industrial specialization and patterns of structural unemployment in the European Union. In H. Kohno, P. Nijkamp and J. Poot (eds) Regional cohesion and competition in the age of globalisation Cheltham UK: Edward Elgar (forthcoming)

Penhale, E.M. 1980 Variations in labour force participation and unemployment of women in New Zealand cities. Paper presented to the Women's Studies Conference, 29-31 August.

Poot, J. 1984 A systems approach to modelling the interurban exchange of workers in New Zealand Scottish Journal of Political Economy 33(3): 249-274

Poot, J. and J. J. Siegers 1992 An economic analysis of fertility and female labour force participation in New Zealand New Zealand Economic Papers 26(2): $219-248$

Prime Ministerial Task Force on Employment 1994 Employment: addressing New Zealand's biggest challenge, proposals for action November(Prime Ministerial Task Force on Employment, Wellington)

Statistics New Zealand 1993 Regional Digest of Statistics Statistics New Zealand

Taylor, J. and S. Bradley 1983 Spatial variations in the unemployment rate: a case study of North West England Regional Studies 17: 113-124

Vaithianathan, R. 1995 The impact of regional unemployment and iwi (tribal) affiliation on internal migration, unpublished MCom thesis, University of Auckland

Vedder, R. and L. Gallaway 1996 Spatial variations in U.S. unemployment Journal of Labor Research XV11(3): 445-461

Waldegrave, C. and S. Stuart 1997 Out of the rat race. The migration of low income urban families to small town Wairarapa New Zealand Geographer 53(1): $22-29$

Wulff, M., M. Bell and J. Cooper 1996 Internal migration, social welfare and settlement patterns: impacts on communities and regions Bureau of Immigration, Multicultural and Population Research, Canberra 


\section{Notes}

1. Early work on regional disparities such as Jensen (1969) and Johnston (1981) contained measures of labour market outcomes but made no attempt to explore differences in the structure and functioning of the regional markets themselves. The significance of regional differences in labour market outcomes were explored in the early 1960s in the McDonald report on regional development and were raised again by Mabbett (1988). The presence of regional disparities has been the subject of several New Zealand Planning Council reports (e.g. 1989). As attention shifted away from regional development and towards addressing individuals per se, regions tended to be used as substitutes for the micro level data rather than as objects of substantive interest themselves. While regions were used in the work of Brooks (1991) and Harris and Raney (1991) and Poot and Siegers (1992) the manifold relationships between labour force participation and the characteristics of their local labour markets were left under explored. None really addressed the questions which Hyman raised much earlier on about the nature and reasons for regional disparities in female labour force participation (Hyman 1978, 1979 and Penhale, 1980). This didn't really change even though there were advances in the modelling of regional interaction notably by Poot (1984). The recent work, typified by Vaithianathan (1995), is now reexamining the role of the regional factor particularly in retarding labour adjustment. It is in the context of this contemporary concern that this paper has been written.

2. Having said this, Statistics New Zealand's publication of the Regional Digest of Statistics was an important step forward (largely due to the efforts of Lowe (see 1988). The regional statistics now available on the SUPERMAP data base are also of considerable value as are those produced through the Statistics New Zealand Household Labour Force Survey.

3. Elsewhere we use the profile to test specific hypothesis about the relationship between labour market competition and the convergence of regional labour markets in New Zealand (see Morrison, 1998a). The central argument advanced in that report is that the more competitive the labour force the less regional differences influence labour market outcomes. Or, putting it another way, it is primarily the location decisions of the less competitive workers which account for the long term persistence in regional labour market disparities.

4. This is distinct from total income as reported in the census. The census relies on the individual respondent to recall their total income. This is defined as income before tax from all sources for the financial year ended 31 March 1991. 'All sources' includes income from 'wages, salary, commission, business or farming income (less expenses), Social Welfare (including Family Support), Accident Compensation weekly payments, interest, dividends, rent, fringe benefits or income in kind, Youth or Student Allowance, Bursary, Scholarship, maintenance from former partner, superannuation and pension payments' (Statistics New Zealand, 1992: manual B -13). In 1991 respondents were asked to tick 'which types of income support' they received during the 12 months prior to 31 March 1991 and then to tick the income category their before tax total annual income falls into (Q14 and 15, Statistics New Zealand, 1997, Individual Form 1991).

5. Whereas the per capita income is available directly from Statistics New Zealand's SUPERMAP2 data base, the per capita wage or salary income has to be estimated from counts over the range of income categories. In our case we multiply the mid point of each income interval by the number of workers in that category, sum the result and divide by the total number of salary earners.

6. The classic US study is Bowen and Finegan (1969) from which very detailed rates may be obtained. While it is difficult to judge precisely, the New Zealand range would appear to be somewhat more restricted than those reported for much larger economies: for example the USA ranged in 1985 from 52.2 percent in West Virginia to 73 percent in Alaska (Gallaway, Vedder and Lawson, 1991:45). For the United Kingdom Gordon (1970:414-5) reports female activity rates (for sub-divisions of the economic planning regions) which range from 28 percent in north-west Wales to 49 percent in Greater London - a range comparable to the New Zealand range of 46.5 to 55.6 percent. Other figures are reported in Bowers (1970) and Mohlo, 1983).

7. The range would appear to be narrower than is found in Europe and US with only a small proportion of this difference to be due to difference in the levels of spatial dissaggregation. Results from a 55 region classification for seven countries in the European Union in 1993 for example revealed an unemployment rate which ranged from $3.9 \%$ in Bayern to $25.9 \%$ in Sur (Munro and Schacter, 1998). Variation in the 'full employment unemployment rate' across 43 local market areas in Pennsylvania, 1971-1982 ranged from $3.19 \%$ to $10.40 \%$ (Hyclak and Johnes, 1987:194). Taylor and Bradley (1983) use a conservative measure of noncyclical unemployment in northwest England which varied from $0.5 \%$ to $7.3 \%$.

8 . Note here that only wage or salary incomes are considered here and omitting earnings of employers or the self-employed and that this may lead to lower relative incomes of predominantly farming areas.

9. Green and Hasluck (1998) propose a graduated range of 'unemployment' measures from the narrow unemployed and seeking work to complete non participation. Their measure of the labour reserve increases as these are added together. Successive measures are then compared across the regions of the UK. They observe how the use of the unemployment rate tends to understate interregional differentials in the size of the labour reserve.

10. The expectation in the neoclassical theory of unemployment rates is actually the reverse of this interpretation, namely, that unemployment is high in some regions because wages are (too) high (as in Hall, 1972) but there is considerable debate over Hall's evidence as well as the underlying argument. 
11. Seasonal economies exhibit low unemployment rates at the peak of the seasons which include March when the census is taken so these (reverse) unemployment rates may be overestimates of their average annual unemployment levels. The same would apply to the Hastings economy. Even if there were no seasonal effects these counter examples could reflect composition effects associated with the level of aggregation: industry and occupational mix effects as well as gender mix effects probably play a larger role at this level than pure wage rate effects. By the same argument one would expect such a relationship to become less ambiguous when estimated for more homogeneous subpopulations. The other and more general reason for the weaker correlation in panel 2 is composition bias. Those who are unemployed are typically quite different from those who are employed, particularly those employed fulltime on wages or salaries. In a highly stratified market it is quite possible for the two types of labour to coexist in the same region but with relatively weak labour market connections between them.

12. Not all of this difference will be due to regional variations in rates of pay of course. There is, as Jackson has pointed out (1997), a strong association between the industrial and occupational mix of a region and incomes.

13.A more robust statistical approach to identifying such types would be to apply cluster analysis to the regions on the basis of their scores on the four indicators.

14. See Morrison (1998b) for a preliminary discussion of the way each of these regions behaved on a number of these indices over the twenty seven quarters between June 1990 and December 1996 as revealed by the Household Labour Force Survey. Subsequent work will compare the profiles of these regions in 1991 with their profiles constructed for the 1996 census.

\section{Author}

Philip Morrison is Senior Lecturer, Institute of Geography, School of Earth Sciences, Victoria University of Wellington, PO Box 600, Wellington. E-mail:

Philip.Morrison@vuw.ac.nz 